Reprod. Nutr. Dévelop., 1982, 22 (6), 1061-1072.

\title{
Morphologic evidence for seasonal changes in the pineal organ of the goldfish, Carassius auratus ; a quantitative study
}

\author{
J. A. McNULTY
}

Department of Anatomy, Loyola University of Chicago, Stritch School of Medicine, Maywood, Illinois 60153, USA.

Summary. A quantitative morphologic study of photoreceptor cells in pineal organ of the goldfish was conducted over a period of one year in which the photoperiodtemperature regime simulated the natural environment. Statistically significant seasonal differences were found in cell size, nuclei, nucleoli, mitochondria, endoplasmic reticulum, and Golgi bodies. Peak values generally occurred during the fall and winter months, while minimum values coincided with the reproductive spring and summer seasons. Histological examination of the gonads indicated that the fish followed the normal sexual cycle. These data suggest that the pineal organ is functionally related to photoperiod, temperature, and gonadal maturation in this species.

\section{Introduction.}

The pineal organ of ectothermic vertebrates is a photoreceptive structure which is hypothesized to play a role in mediating the effects of environmental lighting on the behavior and physiology of these animals. In this regard, recent investigations have provided evidence for a functional relationship between this organ, photoperiod and seasonal reproductive strategies in such diverse species as a lamprey (Joss, 1973), teleost fishes (de Vlaming, 1975; de Vlaming and Vodicnik, 1978 ; Fenwick, 1970 a ; Urasaki, 1972, 1973 ; Vodicnik et al., 1979), amphibians (Rastosi et al., 1976), and reptiles (Levey, 1973). Additional literature on the pineal organ and reproduction in lower vertebrates has been reviewed elsewhere (de Vlaming and Olcese, 1981 ; Vivien-Roels, 1981).

Morphologic studies of the pineal complex of these species, particularly fishes, have generally given little attention to seasonal effects due to variations in photoperiod and the reproductive state of the animal. The importance of these factors is emphasized by reports demonstrating that structural characteristics of

Please send correspondence to : Dr. John A. McNulty, Department of Anatomy, Loyola Univ. Medical Center, Maywood, II. 60153, USA. 
mammalian pinealocytes vary with the season and the reproductive cycle (Frink et al., 1978 ; Legait et al., 1975 ; Lincoln, 1976 ; McNulty and Dombrowski, 1980 ; McNulty et al., 1980 ; Quay, 1976 ; Quay and Millar, 1973). Therefore, the present study was initiated to compare the morphology of the pineal organ of the goldfish, Carassius auratus, in animals exposed to varying photoperiodtemperature conditions aver a period of one year. This species generally follows the natural sexual cycle when exposed to artificial lighting which simulates normal light : dark cycles throughout the year (Fenwick, 1970 a). Earlier anatomical studies have suggested that the pineal organ of the goldfish is highly photosensitive (McNulty, 1981; Takahashi, 1969 ; Wake, 1973).

\section{Materials and methods.}

Goldfish (50-80 mm standard length) were kept in 20 gallon aquaria illuminated by $15-W$ incandescent bulbs (Hagen) at a distance of about $10 \mathrm{~cm}$ from the surface of the water. Automatic timers, adjusted at weekly intervals, were used to synchronize the light : dark cycle with natural sunrise and sunset (fig. 1). The temperature of the room, and consequently the water, was allowed to fluctuate seasonally. Water temperature ranged between $14.8{ }^{\circ} \mathrm{C}$ in January and $28.8{ }^{\circ} \mathrm{C}$ in July (fig. 1).

Five fish were sacrified by decapitation during the middle of the light phase on each of the days listed in table 1. The dorsal cranium with the pineal organ attached was quickly removed with a razor blade and the tissue immersion fixed with 4 p. 100 glutaraldehyde in monobasic phosphate buffer $(340 \mathrm{mOsm}$, $\mathrm{pH}$ 7.3) for one hour. The tissue was postfixed, following a brief buffer wash, with 1 p. 100 osmium tetroxide in phosphate buffer for one hour, dehydrated in a graded series of acetone, and embedded in Epon. The pineal organ was carefully dissected from the cranium before embedding. Thin sections of uniform thickness were cut from the middle two-thirds of the pineal end-vesicle, stained with uranyl acetate and lead citrate, and examined with a RCA EMU-3F electron microscope.

FIG. 1. - The temperature of the water (dashed line) and the hours of daylight (solid line) at the time of each sample.

FIG. 2. - Mean diameter of photoreceptor cell nucleoli over the yearly period. (Vertical lines in each graph indicate one standard error of the mean.)

FIG. 3. - Means of nuclear volumes of photoreceptor cells over the yearly period.

FIG. 4. - Means of photoreceptor cell volume over a yearly period. 


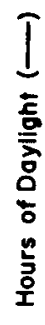

(1)

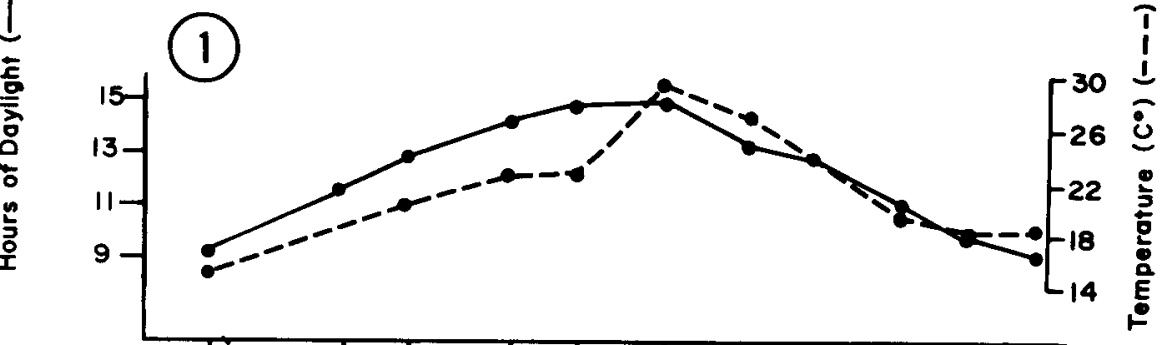

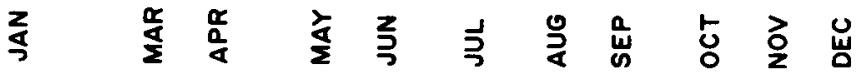

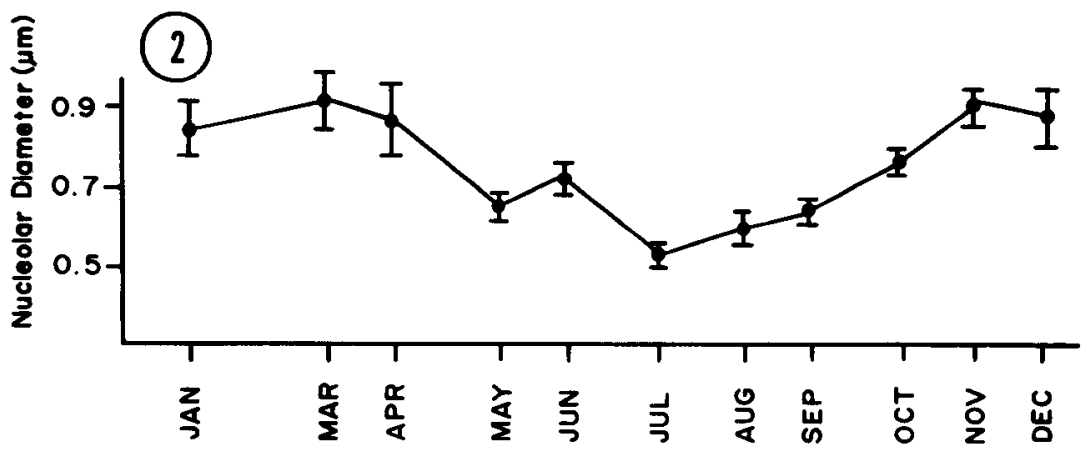

$\stackrel{n}{3}$
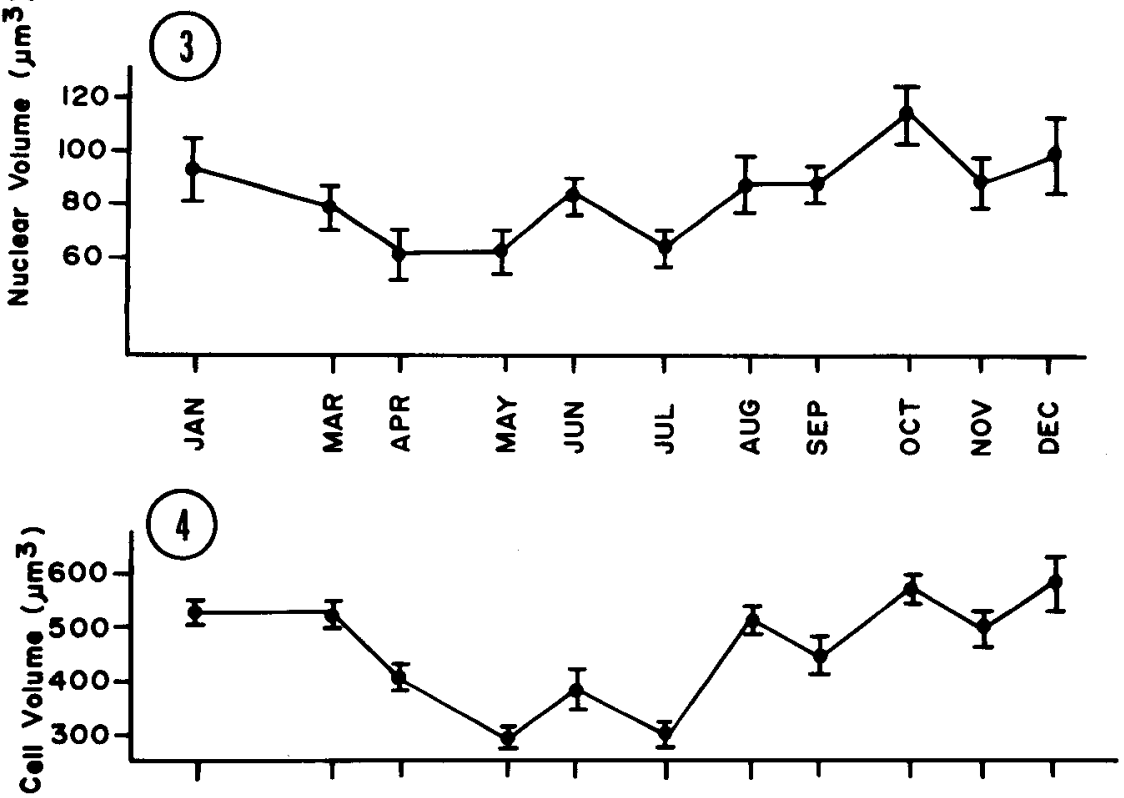

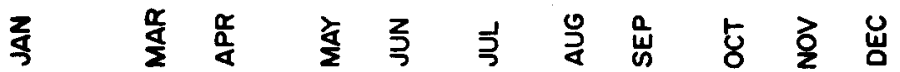


Quantitative analysis of the tissue was by both stereological point-couting techniques and computerized image analyser (Zeiss Videoplan). The volume density $(\mu \mathrm{m} 3 / \mu \mathrm{m} 3)$ of those components listed in table 1 and the numerical density (no. $/ \mu \mathrm{m} 3$ ) of photoreceptor cells were estimated from low magnification electron micrographs ( $\times 5000$ final magnification) using an 88-point transparent grid (Weibel and Bolender, 1973). Approximately 25 micrographs per animal were analyzed using only one section per grid to avoid repetitive measurements on the same cells. The mean volume of each component listed in table 2 was calculated by dividing the volume density of that component by the numerical density of the photoreceptor cells. Numerical density was estimated by the formula $\mathrm{Nv}=1 / \mathrm{B} . \mathrm{Na}^{3 / 2} / \mathrm{Vv}^{1 / 2}$, where $\mathrm{Na}=$ number of nuclei per unit area, $\mathrm{Vv}=$ volume density of nuclei, and $B=$ shape coefficient of the nuclei (Weibel and Bolender, 1973). The shape coefficient of the nucleus was previously calculated to be 1.6 (McNulty, 1981). A computerized image analyzer programmed for stereology was employed as a separate method to estimate the mean volume of nuclei and to measure the diameter of nucleoli (table 3). All of the counts and measurements were made on micrographs that had been previously coded. Means of these variables were calculated for each specimen and grouped according to month. The means and standard errors of these grouped means ( $n=5$ ) were calculated and statistically evaluated using a one-way analysis of variance test.

Additional measurements were made on photoreceptor cell organelles from fish sacrificed in January, April, July, and October. Electron micrographs $(\times 31000$ final magnification) of the supranuclear cytoplasm of every photoreceptor cell found in one section per grid were superimposed with an 88-point transparent grid to obtain estimates of the volume densities of those

TABLE 1

Mean values ( \pm standard errors) for volume densities and numerical density of photoreceptor cells

\begin{tabular}{|c|c|c|c|c|}
\hline $\begin{array}{l}\text { Date of } \\
\text { sacrifice }\end{array}$ & $\begin{array}{c}\text { Volume } \\
\text { density of } \\
\text { photoreceptor } \\
\text { cells }\end{array}$ & $\begin{array}{c}\text { Volume } \\
\text { density of } \\
\text { nuclei }\end{array}$ & $\begin{array}{l}\text { Volume } \\
\text { density of } \\
\text { supranuclear } \\
\text { cytoplasm }\end{array}$ & $\begin{array}{c}\text { Numerical } \\
\text { density of } \\
\text { photoreceptor } \\
\text { cells }\left(\times 10^{-3}\right)\end{array}$ \\
\hline 13 Dec 79 & $.493 \pm .049$ & $.086 \pm .015$ & $.229 \pm .021$ & $.862+.137$ \\
\hline 26 Jan 80 & $.493 \pm .019$ & $.087 \pm .012$ & $.287 \pm .011$ & $.944 \pm .182$ \\
\hline $12 \operatorname{mar} 80$. & $.491 \pm .023$ & $.074 \pm .008$ & $.269 \pm .024$ & $.938 \pm .098$ \\
\hline 9 Apr 80 & $.493 \pm .023$ & $.076 \pm .014$ & $.271 \pm .016$ & $1.232 \pm .099$ \\
\hline 19 May 80 & $.492 \pm .032$ & $.108 \pm .015$ & $.238 \pm .030$ & $1.696 \pm .475$ \\
\hline 11 Jun 80 . & $.494 \pm .053$ & $.112 \pm .006$ & $.273 \pm .020$ & $1.286+.202$ \\
\hline 16 Jul 80 . . & $.494 \pm .036$ & $.111 \pm .013$ & $.271 \pm .022$ & $1.712+.127$ \\
\hline 19 Aug 80 & $.543 \pm .022$ & $.094 \pm .012$ & $.312 \pm .026$ & $1.048 \pm .089$ \\
\hline 12 Sep 80 & $.439 \pm .036$ & $.088 \pm .008$ & $.218 \pm .025$ & $.988 \pm .106$ \\
\hline 15 Oct 80 & $.507 \pm .020$ & $.104 \pm .012$ & $.291 \pm .018$ & $.902 \pm .047$ \\
\hline 11 Nov 80 & $.491 \pm .025$ & $.091 \pm .011$ & $.279 \pm .018$ & $1.012 \pm .089$ \\
\hline F value .. & 0.59 & 1.57 & 2.00 & 3.26 \\
\hline$p$ value $^{a} \ldots \ldots \ldots \ldots \ldots$ & $>0.25$ & $>0.10$ & $>0.05$ & $<0.005$ \\
\hline
\end{tabular}

a Degrees of freedom equal 10, 44 . 
organelles listed in table 4 . Because volume densities do not take into account changes in cell size, the volume densities were multiplied by the mean profile area of the supranuclear cytoplasm and the mean volume of this compartment of the cell (table 5). Lastly, the mean profile area and the length of the longest axis of each Golgi body were measured with a Zeiss Videoplan (table 6). Means of the variables were again calculated for each specimen and grouped according to month. Differences between maximum and minimum values were evaluated using t-statistics.

The gonads from fish sacrificed in January, April, July, and October were dissected, fixed in 10 p. 100 buffered formalin, embedded in methacrylate, sectioned at a thickness of $5 \mu \mathrm{m}$, and stained with toluidine blue. Maturational changes in the ovaries were separated according to size range of the 25 largest oocytes and the amount of yolk into the following stages : I. oocytes with no yolk, diameter between 65-125 $\mu \mathrm{m}$, II. oocytes with small yolk vesicles along periphery, diameter 100-200 $\mu \mathrm{m}$, III. oocytes with yolk vesicles throughout cytoplasm, diameter 200-500 $\mu \mathrm{m}$, IV. mature oocytes greater than $500 \mu \mathrm{m}$. Maturational changes in the testes were separated into the following stages: I. seminiferous tubules small and devoid of spermatocytes, no spermatogonia, II. seminiferous tubules small, spermatogonia with mitotic figures present, III. cysts containing spermatids are present, some spermatozoa in lumina, IV. seminiferous tubules swollen and filled with spermatozoa.

\section{Results.}

The mean volumes of photoreceptor cells, nuclei, and the supranuclear cytoplasm estimated according, to point-counting techniques showed statistically significant differences over the period of one year (table 2). Computerized image

TABLE 2

Mean values ( \pm standard errors) for volumes of photoreceptor cel/s, nuclei, and supranuclear cytoplasm

\begin{tabular}{|c|c|c|c|}
\hline Month & $\begin{array}{c}\text { Volume of } \\
\text { photoreceptor } \\
\text { cells }\left(\mu \mathrm{m}^{3}\right)\end{array}$ & $\begin{array}{l}\text { Volume of } \\
\text { nuclei }\left(\mu \mathrm{m}^{3}\right)\end{array}$ & $\begin{array}{c}\text { Volume of } \\
\text { supranuclear } \\
\text { cytoplasm }\left(\mu \mathrm{m}^{3}\right)\end{array}$ \\
\hline December & $573.8 \pm 57.3$ & $100.5 \pm 17.6$ & $266.2 \pm 24.9$ \\
\hline January ... & $525.0 \pm 20.2$ & $92.5 \pm 13.5$ & $305.8 \pm 11.1$ \\
\hline March $\ldots$. & $522.2 \pm 24.4$ & $78.9 \pm 9.0$ & $286.2 \pm 25.7$ \\
\hline April .... & $401.0 \pm 18.9$ & $62.1 \pm 11.2$ & $220.2 \pm 15.0$ \\
\hline May & $289.4 \pm 18.8$ & $63.3 \pm 8.8$ & $140.0 \pm 17.7$ \\
\hline June & $383.0 \pm 41.7$ & $86.5 \pm 4.5$ & $211.8 \pm 15.5$ \\
\hline July .. & $288.6 \pm 20.6$ & $64.8 \pm 7.6$ & $158.4 \pm 12.8$ \\
\hline August .... & $516.8 \pm 20.6$ & $89.3 \pm 11.1$ & $296.5 \pm 25.1$ \\
\hline September & $443.2 \pm 35.6$ & $88.9 \pm 7.7$ & $220.2 \pm 25.1$ \\
\hline October $\ldots \ldots \ldots \ldots \ldots \ldots \ldots$ & $563.6 \pm 22.0$ & $115.1 \pm 12.6$ & $323.0 \pm 20.1$ \\
\hline November $\ldots \ldots \ldots \ldots \ldots \ldots \ldots$ & $486.6 \pm 24.8$ & $90.1 \pm 10.6$ & $276.2 \pm 17.5$ \\
\hline F value $\ldots \ldots \ldots$ & 14.01 & 2.85 & 11.60 \\
\hline$p$ value $\ldots \ldots \ldots \ldots \ldots \ldots \ldots$ & $<0.001$ & $<0.01$ & $<0.001$ \\
\hline
\end{tabular}

a Degrees of freedom equal $10,44$. 
analysis indicated significant differences in the size of nucleoli, and substantiated the changes in nuclear volume estimated by point-counting (table 3). However, nuclear volumes were consistently smaller when calculated by the latter method. The maximum values of these variables occurred during the fall and winter months when daylength was shortest and the water temperature lowest, while minimum values coincided with that time of the year (sping and summer) when this species is normally sexually active (figs. 2-4).

\section{TABLE 3}

Mean value ( \pm standard errors) for nuclear volume and nucleolar diameter using computerized image analysis

\begin{tabular}{|c|c|c|}
\hline Month & $\begin{array}{c}\text { Volume of } \\
\text { nuclei }\left(\mu \mathrm{m}^{3}\right)\end{array}$ & $\begin{array}{l}\text { Diameter of } \\
\text { nucleoli }(\mu \mathrm{m})\end{array}$ \\
\hline December ..... & $82.6 \pm 11.5$ & $0.87 \pm 0.07$ \\
\hline January ... & $70.4 \pm 14.2$ & $0.84 \pm 0.06$ \\
\hline March .... & $72.1 \pm 8.9$ & $0.90 \pm 0.03$ \\
\hline April .. & $58.9 \pm 8.0$ & $0.86 \pm 0.10$ \\
\hline$\ldots \ldots \ldots$ & $54.6 \pm 5.7$ & $0.65 \pm 0.03$ \\
\hline June. & $77.2 \pm 11.2$ & $0.72 \pm 0.04$ \\
\hline July .. & $49.5 \pm 6.3$ & $0.54 \pm 0.02$ \\
\hline August $\ldots \ldots$ & $71.9 \pm 7.6$ & $0.60 \pm 0.04$ \\
\hline September ... & $77.4 \pm 10.0$ & $0.64 \pm 0.03$ \\
\hline October $\ldots \ldots \ldots$ & $96.6 \pm 10.7$ & $0.77 \pm 0.03$ \\
\hline November ....... & $80.0 \pm 13.8$ & $0.90 \pm 0.04$ \\
\hline F value ...... & 2.18 & 5.40 \\
\hline p value $\ldots .$. & $<0.05$ & $<0.001$ \\
\hline
\end{tabular}

a Degrees of freedom equal 10, 44.

The mean profile area of the supranuclear cytoplasm measured from high magnification electron micrographs was significantly greater in January compared to July (table 4). These data corresponded to the volumetric changes in this cellular compartment estimated by point-counting analysis. Volume

TABLE 4

Mean values ( \pm standard errors) of cytoplasmic components in supranuclear cytoplasm

\begin{tabular}{lccccc}
\hline Month & $\begin{array}{c}\text { Volume density } \\
\text { of } \\
\text { mitochondria }\end{array}$ & $\begin{array}{c}\text { Volume density } \\
\text { of endoplasmic } \\
\text { reticulum }\end{array}$ & $\begin{array}{c}\text { Volume density } \\
\text { of } \\
\text { Golgi bodies }\end{array}$ & $\begin{array}{c}\text { Golgi bodies } \\
\text { per unit area } \\
\left(\mu \mathrm{m} \times 10^{-1}\right)\end{array}$ & $\begin{array}{c}\text { Profile area of } \\
\text { supranuclear } \\
\text { cytoplasm }\left(\mu \mathrm{m}^{2}\right)\end{array}$ \\
\hline January $\ldots \ldots$ & $.153 \pm .020$ & $.223^{*} \pm .008$ & $.059 \pm .008$ & $.213 \pm .031$ & $11.13^{*} \pm 0.43$ \\
April $\ldots \ldots \ldots$ & $.163^{*} \pm .044$ & $.218 \pm .017$ & $.078^{*} \pm .008$ & $.225^{*} \pm .015$ & $10.49^{*} \pm 0.53$ \\
July $\ldots \ldots \ldots$ & $.240^{*} \pm .022$ & $.216 \pm \pm 0.14$ & $.056 \pm .004$ & $.204 \pm .020$ & $9.28^{*} \pm 0.49$ \\
October $\ldots \ldots$ & $.147 \pm .016$ & $.202^{*} \pm .013$ & $.048^{*} \pm . .007$ & $.170^{*} \pm .022$ & $10.93 \pm 0.63$ \\
t value $\ldots \ldots$ & 0.55 & 1.59 & 3.25 & 2.13 & 3.18 \\
p value $\ldots \ldots$ & $>0.25$ & $>0.05$ & $<0.05$ & $<0.05$ & $<0.01$ \\
\hline
\end{tabular}

a Degrees of freedom equals 8 .

Asterisks indicate maximum and minimum values analyzed by t-statistics. 


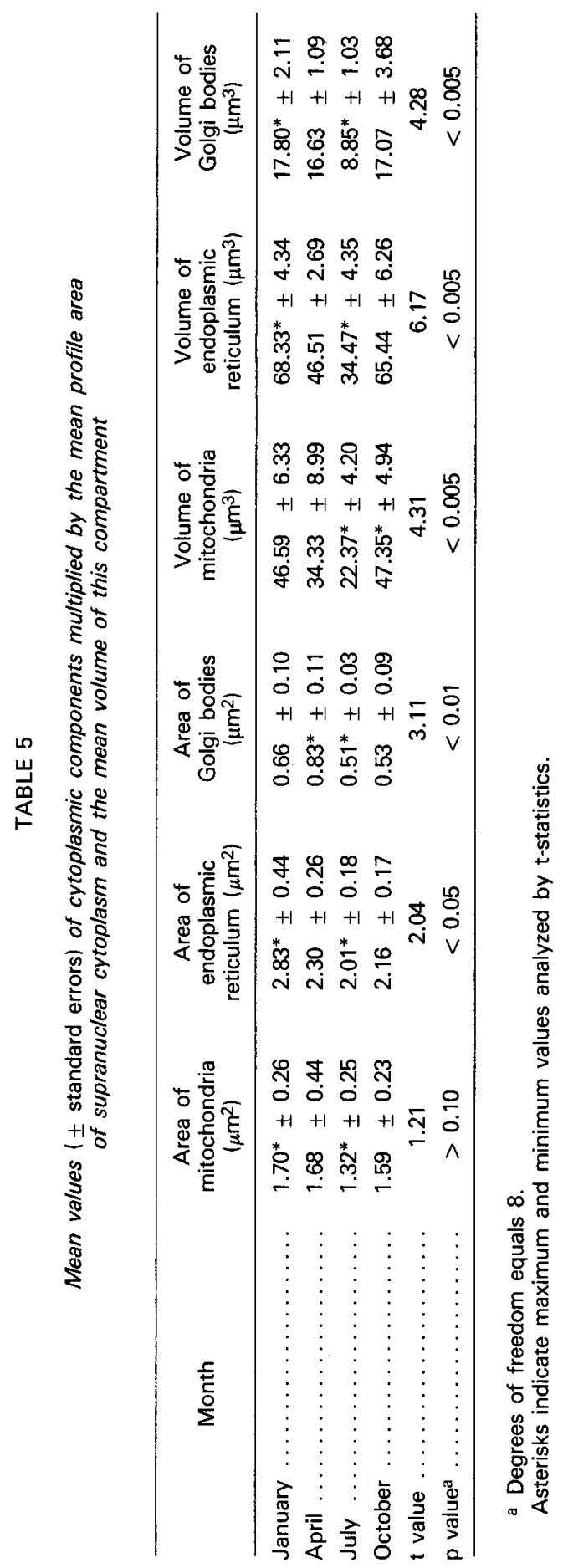


densities of Golgi bodies present in this part of the cell were significantly higher in April, while no changes were found in mitochondria and endoplasmic reticulum (table 4). However, multiplying these volume densities by either the mean profile area or volume of the supranuclear cytoplasm resulted in a significant decline in each of these organelles during the month of July (table 5).

The number of Golgi bodies per unit area of cytoplasm, the mean profile area, and the length of the greatest axis of this organelle all had maximum values in April, just prior to the onset of the spawning (tables 4,6). There was a significant reduction in the size and number of Golgi bodies during July and October, respectively.

TABLE 6

Mean valu: ( \pm standard errors) of profile area and longest axis of Golgi bodies

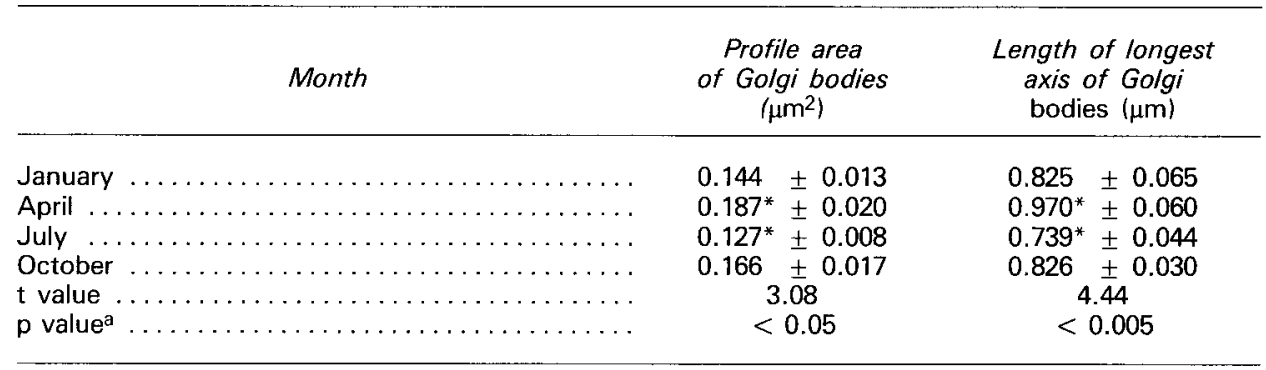

a Degrees of freedom equals 8.

Asterisks indicate maximum and minimum values analyzed by t-statistics.

It was not possible to separate the fish by sex prior to sacrificing the animals. Consequently, the number of fish in each sex varied from month to month. Histological examination of the gonads suggested that the fishes used in this study followed the normal sexual cycle (table 7). Females sacrificed during the month of April had oocytes which were either mature (stage IV) or contained a large amount of yolk granules (stage III). Of the two males sacrificed during this month, one had seminiferous tubules swollen with spermatozoa (stage IV). The ovaries of all females sacrificed in July had small oocytes with a strongly basophilic cytoplasm. Intermediate stages of gonadal maturation were found in animals sacrificed in the fall and winter months.

TABLE 7

Maturational stage of gonads. The number of fish in each stage is indicated for individual months

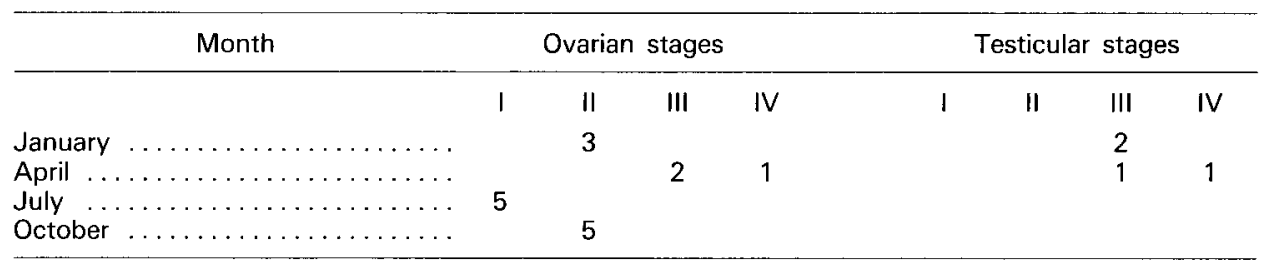




\section{Discussion.}

The results presented in this study provide morphological evidence for functional changes in the pineal organ of the goldfish, which are inversely related to daylength, temperature, and the reproductive state of the animals over a period of one year. Accordingly, these data support a hypothesis that the pineal organ of lower vertebrates plays a role in mediating the effects of these fluctuating environmental conditions on reproduction.

A functional relationship between the pineal organ, photoperiod, and gonadal maturation has been suggested for several fish species. The gonosomatic index in goldfish was found to be most responsive to altered daylength during those months preceding the reproductive period (Fenwick, 1970 a). Pinealectomy in this species reversed regression of gonadal activity caused by short daylength (Fenwick, 1970 a ; de Vlaming and Vodicinik, 1978), or repressed the stimulatory effects of long photoperiod (de Vlaming and Vodicinik, 1978 ; Hontela and Peter, 1980), but only during the winter and spring months. Similar effects of pinealectomy on gonadal development have been reported for the medaka (Urasaki, 1972, 1973) and the golden shiner (de Vlaming, 1975).

The present findings that nuclei and nucleoli of photoreceptor cells peaked in size between October and March, when the gonads are most responsive to pinealectomy, imply that the level of activity of these cells in heightened during these seasons of short photoperiod. This suggestion is supported by the observation that photoreceptor-cell nuclei and nucleoli in the pineal organ of the trout were significantly larger in fishes subjected to constant darkness than in fishes raised under alternating light: dark cycles of various wavelengths or continual light (Hafeez et al., 1978).

Modifications in the size of nuclei and nucleoli have been used as indicators of cellular metabolic activity (Busch and Smetana, 1970 ; Rather, 1958). Several investigations on mammalien pinealocytes have correlated size changes in these cellular components with daily patterns in protein synthesis and RNA content in the pineal gland of the rat (Nir et al., 1971; Quay and Renzoni, 1966), and with seasonal reproductive cycles of the rock hydrax (Quay and Millar, 1973), the dormouse (Legait et al., 1975), the hare (Lincoln, 1976), two species of bats (Quay, 1976), and the 13-lined ground squirrel (McNulty et al., 1980). In each of these seasonally reproductive species, there was a trend for an inverse temporal relationship between nuclear and nucleolar dimensions and reproductive functions.

Further evidence for seasonally related changes in the level of activity of photoreceptor cells included quantifiable alterations in mitochondria, endoplasmic reticulum, and Golgi bodies found in the supranuclear cytoplasm. The greater volume of mitochondria and endoplasmic reticulum during October and January correlates with increased size of nucleoli, and suggests a greater energy demand possibly in terms of protein synthesis. An earlier study showed that the majority of endoplasmic reticulum in this part of the cell was associated with ribosomes 
(McNulty, 1981). Seasonal patterns in the Golgi bodies indicated that this organelle peaked in number and absolute size in April, just prior to the spawning season in nature. Although the functional significance of morphological variations in Golgi bodies is not clear, similar increases in size and number of these organelles were reported in pinealocytes of the mole (Pevet and Smith, 1975), the woodchuck (Frink et al., 1978), and a ground squirrel (McNulty and Dombrowski, 1980) preceding or during the reproductive period.

The observed morphological responses of photoreceptor cells may be related to cellular activities associated with photoreception (e.g., the production of neurotransmitter and photopigments) and with neuroendocrine functions attributed to the pineal organ of fishes. Histochemical, immunocytochemical, and biochemical studies have demonstrated that pineal cells in these species contain the indoles, 5-hydroxytryptophan, 5-hydroxytryptamine (serotonin) and melatonin (Falcon et al., 1980, 1981 ; Fenwick, $1970 \mathrm{~b}$; Hafeez and Zerihun, 1976 ; Meissl et al., 1978 ; Owman and Rudeberg, 1970 ; Vivien-Roels et al., 1981), and the enzyme, hydroxyindole-O-methyl transferase (HIOMT), that is responsible for catalyzing the methylation of $\mathrm{N}$-acetylserotonin to melatonin (Birks and Ewing, 1981 a ; Hafeez and Quay, 1970 ; Smith and Weber, 1974, 1976). Levels of these compounds and protein content fluctuate over daily light : dark cycles (Birks and Ewing, $1981 \mathrm{~b}$; Falcon et al., 1980 ; Meissl et al., 1978; Smith and Weber, 1974,1976 ). Furthermore, seasonal variations in serotonin content were reported in the pineal complex of a lamprey with low levels occurring during the spawning period (Meiniel and Vivien-Roels, 1981). The rhythmic production and release of these compounds, especially melatonin, under varying environmental conditions may modulate reproductive cycles among other physiologic processes. Melatonin administration altered gonadal maturation in the goldfish (Fenwick, $1970 \mathrm{~b}$ ), and the killifish (de Vlaming et al., 1974) ; the effects generally depending upon the time of year and photoperiod. On the basis of these observations, it would be important to determine the effects of various photoperiod-temperature regimes on circadian rhythms of indoles and their related enzymes.

Reçu en mai 1982. Accepté en août 1982.

Acknowledgements. - The technical assistance of Miss Melissa Lopez and Mrs. Dwan Taylor is gratefully acknowledged. Supported by NSF Grant (BNS 79-04245).

Résumé. Mise en évidence et étude quantitative des changements morphologiques saisonniers dans l'organe pinéal du poisson rouge, Carassius auratus.

Une étude morphologique quantitative des cellules photoréceptrices dans l'organe pinéal du poisson rouge a été réalisée au cours d'une période d'un an pendant laquelle le régime lumineux et la température simulaient les conditions naturelles. II existe des différences statistiques saisonnières dans la taille des cellules, des noyaux, des nucléoles et le volume des mitochondries, du reticulum endothélial et des corps de Golgi. Les valeurs maximales sont généralement rencontrées pendant les mois d'automne et d'hiver, tandis que les minimales coïncident avec la période de reproduction : printemps et été. L'examen histologique des gonades montre que les poissons ont un cycle sexuel normal. Ces données suggèrent que, dans cette espèce, le fonctionnement de la glande pinéale est en rapport avec la photcpériode et avec la maturation des gonades. 


\section{References}

BIRKS E. K., EWING, R. D., 1981 a. Characterization of hydroxyindole-O-methyltransferase (HIOMT) from the pineal gland of Chinook salmon (Oncorhynchus tsbawytsch). Gen. comp. Endocrinol., 43, 269-276.

BIRKS E. K., EWING R. D., 1981 b. Photoperiod effects on hydroxyindole-O-methyltransferase activity in the pineal gland of Chinook salmon (Oncorhynchus tsbawytsch). Gen. comp. Endocrinol., 43, 277-283.

BUSCH H., SMETANA K., 1970. The nucleolus. Acad. Press, New York, $626 \mathrm{pp}$

De VLAMING V. L., 1975. Effects of pinealectomy on gonadal activity in the cyprinid teleost, Notemigonus crysoleucus. Gen. comp. Endocrinol., 26, 36-49.

De VLAMING V. L., MARTIN S., CHARLTON C. B., 1974. The effects of melatonin treatment on gonosomatic index in the teleost, Fundulus similis, and the tree frog, Hyla cinera. Gen. comp. Endocrinol., 22, 433-438.

De VLAMING V., OLCESE J., 1981. The pineal and reproduction fish, amphibians, and reptiles. In : R. J. REITER, The pineal gland, Vol. II, CRC Press, Boca Raton, FI.

De VLAMING V. L., VODICNIK M. J., 1978. Seasonal effects of pinealectomy on gonadal activity in the goldfish, Carassius auratus. Biol. Reprod., 19, 57-63.

FALCON J., GEFFARD M., JUILLARD M. T., DELAAGE M., COLLIN J. P., 1981. Melatonin-like immunoreactivity in photoreceptor cells. A study in the teleost pineal organ and the concept of photoneuroendocrine cells. Biol. cell., 42, 65-68.

FALCON J., JUILLARD M. T., COLLIN J. P., 1980. L'organe pineal du Brochet (Esox lucius, L.). IV. Sérotonine endogène et activité monoamine oxydasique; étude histochimique, ultracytochimique et pharmacologique. Reprod. Nutr. Dévelop., 20, 139-154.

FENWICK J. C., 1970 a. The pineal organ : photoperiod and reproductive cycles in the goldsfish, Carassius auratus L. J. Endocrinol., 46, 101-111.

FENWICK J. C., 1970 b. Demonstration and effect of melatonin in fish. Gen. comp. Endocrinol., 14, 86-97.

FRINK R., KRUPP P. P., YOUNG R. A., 1978. Seasonal ultrastructural variations in pinealocytes of the woodchuck, Marmota monax. J. Morph., 158, 91-108.

HAFEEZ M. A., QUAY W. B., 1970. Pineal acetylserotonin methyltransferase activity in the teleost fishes, Hesperoleucus symmetricus and Salmo gairdneri, with evidence for lack of effect of constant light and darkness. Comp. Gen. Pharmacol., 1, 257-262.

HAFEEZ M. A., WAGNER H. H., QUAY W. B., 1978. Mediation of light induced changes in the pineal receptor and supporting cell nuclei and nucleoli in stellhead trout (Salmo gairdneri). Photochem. Photobiol., 28, 213-218.

HAFEEZ M. A., ZERIHUN L., 1976. Autoradiographic localization of $3 \mathrm{H}-5 \mathrm{HTP}$ and $3 \mathrm{H}-5-\mathrm{HT}$ in the pineal organ and circumventricular areas of the rainbow trout, Salmo gairdneri Richardson. Cell. Tiss. Res., 170, 61-76.

HONTELA A., PETER R. E., 1980. Effects of pinealectomy, blinding, and sexual condition on serum gonadotropin levels in the goldfish. Gen. comp. Endocrinol., 40, 168-179.

JoSS J. M. P., 1973. Pineal-gonad relationships in the lamprey Lampetra fluviatilis. Gen. comp. Endocrinol., 21. 118-122.

LEGAIT H., ROUX M., DUSSART G., RICHOUX J. P., CONTET-AUDONNEAU J. L., 1975. Données morphométriques sur la glande pinéale du Loir (G/is glis) et du Lérot (Eliomys guercinus) au cours du cycle annuel. C. R. Soc. Biol., 169, 132-136.

LEVEY I. L., 1973. Effects of pinealectomy and melatonin injections at different seasons on ovarian activity in the lizard Anolis carolnensis. J. exp. Zool., 185, 169-174.

LINCOLN G. A., 1976. Seasonal changes in the pineal gland related to the reproductive cycle of the male hare, Lepus europaeus. J. Reprod. Fert., 46, 489-491.

McNULTY J. A., 1981. A quantitative morphological study of the pineal organ in the goldfish, Carassius auratus. Canad. J. Zool., 59, 1312-1325.

McNULTY J. A., DOMBROWSKI T. A., 1980. Ultrastructural evidence for seasonal changes in pinealocytes of the 13-lined ground squirrel, Spermophilus tridecemlineatus: A qualitative and quantitative study. Anat. Rec., 196, 387-400.

McNULTY J. A., DOMBROWSKI T. A., PURRIER W. A., 1980. A seasonal study of pinealocytes in the 13-lined ground squirrel, Spermophilus tridecemlineatus. Reprod. Nutr. Dévelop., 20. 665-672.

MEINIEL A., VIVIEN-ROELS B., 1980. Circannual variations of serotonin in the pineal complex of ammocoetes prior to metamorphosis and metamorphosing forms of Lampetra planeri (Petromyzontidae). Adv. Biosci., 29, 217-221. 
MEISSL H., DONLEY C. S., WISSLER J. H., 1978. Free amino acids and amines in the pineal organ of the rainbow trout (Sa/mo gairdneri) : influence of light and dark. Comp. Biochem. Physiol, 61, 401-405.

NIR I., HIRSCHMANN N., SULMAN F. G., 1971. Dirunal rhythms of pineal nucleic acids and protein. Neuroendocrinology, 7, 271-277.

OWMAN C., RUDEBERG C., 1970. Light, fluorescence, and electron microscopic studies on the pineal organ of the pike, Esox lucius L., with special regard to 5-hydroxytryptamine. $Z$. Zellforsch., 107, 522-550.

PÉVET P., SMITH A. R., 1975. The pineal gland of the mole (Talpa europaea L.) II. Ultrastructural variations observed in the pinealocytes during different parts of the sexual cycle. $J$. neural Trans., 36, 277-248.

QUAY W. B., 1976. Seasonal cycle and physiological correlates of pinealocyte nuclear and nucleolar diameters in the bats, Myotis lucifugus and Myotis sodalis. Gen. comp. Endocrinol., 29, 369-375.

QUAY W. B., MILLAR R. P., 1973. Cytological evidence for reduction in pinealocyte activity during seasonal sexual activity in the male rock hyrax, Procavia capensis. Amer. Zool., 13. 1288.

QUAY W. B., RENZONI A., 1966. Twenty-four-hour rhythms in pineal mitotic activity and nuclear and nucleolar dimensions. Growth, 30, 315-324.

RASTOSI R. K., TELA L., SAXENA P. K., CHIEFFI G., 1976. The control of spermatogenesis in the green frog, Rana esculenta. J. exp. Zool., 196, 151-165.

RATHER L. J.,' $1958 .{ }^{--}$The significance of nuclear size in physiological and pathological processes. Ergebn. allg. Pathol. pathol. Anat., 38, 127-299.

SMITH J. R., WEBER L. J., 1974. Diurnal fluctuations in acetylserotonin and acetylserotonin methyltransferase (ASMT) activity in the pineal gland of the steelhead trout (Salmo gairdneri). Proc. Soc. exp. Biol. Med., 147, 441-443.

SMITH J. R., WEBER L. J., 1976. The regulation of day-night changes in hydroxyindole-O-methyltransferase activity in the pineal gland of the steelhead trout (Salmo gairdneri). Canad. J. Zool., 54, 1530-1534.

TAKAHASHI H., 1969. Light and electron microscopic studies on the pineal organ of the goldfish, Carassius auratus L. Bull. Fac. Fish., Hokkaido Univ., 20, 143-157.

URASAKI H., 1972. Effect of pinealectomy on gonadal development in the Japanese killifish (medaka), Oryzias latipes. J. exp. Zool., 185, 241-246.

URASAKI H., 1973. Effect of pinealectomy and photoperiod on oviposition and gonadal development in the fish, Oryzias latipes. J. exp. Zool., 185, 241-246.

VIVIEN-ROELS B., 1981. Pineal control of reproduction in non-mammalian vertebrates, 315-334. In: A. OKSCHE and P. PEVET, The pineal organ: photobiology-biochemistryendocrinology, Elsevier.

VIVIEN-ROELS B., PÉVET P., DUBOIS M. P., ARENDT J., BROWN G. M., 1981. Immunohistochemical evidence for the presence of melatonin in the pineal gland, the retina and the Harderian gland. Cell Tiss. Res., 217, 105-115.

VODICNIK M. J., OLCESE J., DELAHUNTY G., de VLAMING V., 1979. The effects of blinding, pinealectomy and exposure tu constant dark conditions on gonadal activity in the female goldfish, Carassius auratus. Env. Biol. Fish, 4, 173-177.

WAKE K., 1973. Acetylcholinesterase-containing nerve cells and their distribution in the pineal organ of the goldfish, Carassius auratus. Z. Zellforsch., 145, 287-298.

WEIBEL E. R., BOLENDER R. P., 1973. Stereological techniques for electron microscopic morphometry. In : M. A. HAYAT, Principles and techniques of electron microscopy: Biological applications. Vol. 3, 237-296. Van Nostrand Reinhold Co., N. Y. 